\title{
The Virtual Learning Resource Center for the Digital Manpower
}

\author{
Panita Wannapiroon ${ }^{1}$, Prachyanun Nilsook ${ }^{1}$, Nutthapat Kaewrattanapat ${ }^{2}$, Naphong Wannapiroon ${ }^{3} \&$ Wera Supa $^{4}$ \\ ${ }^{1}$ King Mongkut's University of Technology North Bangkok, Bangkok, Thailand \\ ${ }^{2}$ Suan Sunandha Rajabhat University, Bangkok, Thailand \\ ${ }^{3}$ Rajamangala University of Technology Suvarnabhumi, Phranakhon Si Ayutthaya, Thailand \\ ${ }^{4}$ Rajamangala University of Technology Tawan-ok, Bangkok, Thailand \\ Correspondence: Nutthapat Kaewrattanapat, Suan Sunandha Rajabhat University, Bangkok, Thailand.
}

\author{
Received: April 15, $2021 \quad$ Accepted: May 24, $2021 \quad$ Online Published: August 22, 2021 \\ doi:10.5539/ies.v14n9p28 URL: https://doi.org/10.5539/ies.v14n9p28
}

\begin{abstract}
This research aims to develop the models of Virtual Learning Resource Center (VLRC) for the digital manpower. The results of the research are that: 1) The VLRC development process consists of 5 steps: requirements analysis, planning and designing, prototyping and testing, implementing and monitoring, and evaluation and reporting. 2) The VLRC for the digital manpower consists of two models: 2.1) the physical learning resource, which is a physical space that the learner can actually touch. It can be divided into 5 categories: location-based learning resources, human-based learning resources, material-based learning resources, equipment-based learning resources, and event-based learning resources; and 2.2) the digital learning resource, which is a virtual space that learners can access through information and communication technology tools. It can be divided into 5 categories: search engine and translator's tools, management and storage tools, distance learning tools, content creation, presentation and dissemination tools, social networking and online learning communities' tools. 3) The goals of VLRC development are learning to know, learning to do, learning to live together, and learning to be.
\end{abstract}

Keywords: virtual learning resource center, learning resource center, virtual space, digital manpower

\section{Introduction}

Thailand 20-year strategy (2018-2037) for human resource development and empowerment focuses on the important development goals that will develop people of all backgrounds and all ages to be good, smart, and quality people. People are expected to develop their habit of learning and self-development continuously throughout their life. Each person could then become a highly skilled Thai person, an innovator, thinker, entrepreneur, modern farmer, and/or others (World Bank Group, 2019). With an emphasis on right livelihoods based on their aptitudes, the strategy focuses on the development of qualitative people at all ages: (1) pregnancy/early childhood, focusing on preparing parents before pregnancy; (2) During school-age/adolescence, it focuses on cultivating goodness, disciplines, and developing learning skills that correspond to the 21 st century; (3) The labor age period, which focuses on enhancing potential, skills and labor competencies, in line with market demand; and (4) The aging period, which focuses on promoting the elderly as a driving force in the country.

Recent developments in science, technology, and digital such as communication technology and biotechnology have dramatically changed the patterns of production, business, and people's lives. Humans can communicate by means of both audio and video without borders. As more and more businesses and transactions on digital networks, technology-based countries enable economic development to leapfrog economic growth, develop people, and properly support infrastructure, technology can be introduced to solve many social problems and raise the standard of quality of life. Digital transformation will result in the creation of more and more irregular jobs, while currently many careers may disappear from the local job market (Chalapati \& Chalapati, 2020), and some occupations will be replaced by automation, the pressure on wages tends to decline, which inevitably affects the stability of the life of workers.

Technology in the digital age helps create a harmony and unity integration of the Physical Learning Environment and the Digital Learning Environment (Nilsen, Almås, \& Gram, 2020). Fundamental technology, hardware technology, access technology, and application technology enable learners to learn from every time, everywhere, and from every device, by connecting via the Internet, open educational resources, supplying a learning resource 
for everyone to access (John, Thavavel, Jayaraj, Muthukumar, \& Jeevanandam, 2016). Supplying learners' access to open learning creates a space for learners to have access to different resources, as well as virtual resources (Holder \& Bethea-hampton, 2018). Whether or not learners are moved to various locations, they can control their self-paced learning, according to the context of their career pathways and workplace environment.

Learning resources for working people are the main concepts aimed at working with the main target groups. "Workers in the organization" are the key and core strength of the family, organization, community, and society, by using the eight foundations of happiness. According to Vasantanarat, Duangkota, and Thikaewsri (2013), these Eight foundations are guidelines for managing a sustainable happy life, creating a positive attitude towards life perspective, living with others, social responsibility, and being a good member of the family, the organization, and society. With true happiness based on Eight happiness, 8 types of happiness are: happy body, happy heart, happy society, happy relax, happy brain, happy soul, happy money, and happy family (Kaewpijit \& Utsahajit, 2010).

\section{Research Objectives}

To study a virtual learning resource center for the digital manpower for public and private sectors.

To develop the guidelines for developing a virtual learning resource center for the digital manpower for public and private sectors.

\section{Research Methodology}

\subsection{Analysis of Virtual Learning Resource for the Digital Manpower}

In this study of the usage models and the successful use of virtual learning resource center for the digital manpower, the researcher has studied principles, concepts, theories and available related research resources from books, documents, articles, research reports and research databases both domestically and internationally, that have been recognized both within the country and abroad. These are to be used in the analysis and types of virtual learning resources in the digital era with the research results, respectively. The results of analysis of virtual learning resources in the digital age are as follows.

Table 1. Analysis of virtual learning resource for the digital manpower

\begin{tabular}{|c|c|c|c|c|c|c|c|c|c|c|c|}
\hline Virtual learning resource for the digital manpower & 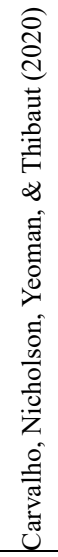 & 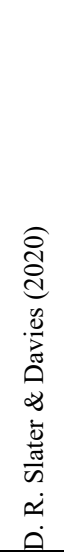 & 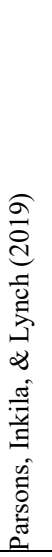 & 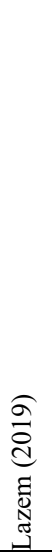 & 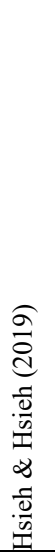 & 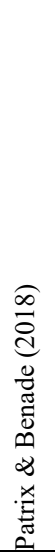 & 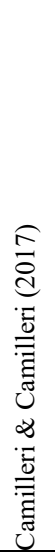 & 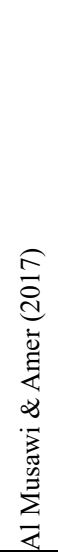 & 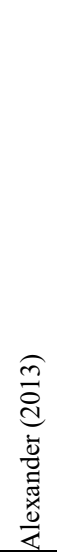 & 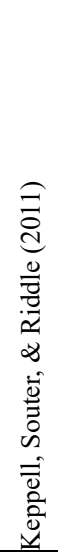 & 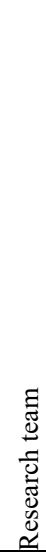 \\
\hline Physical Learning Resources & $\checkmark$ & $\checkmark$ & $\checkmark$ & $\checkmark$ & $\checkmark$ & $\checkmark$ & $\checkmark$ & $\checkmark$ & $\checkmark$ & $\checkmark$ & $\checkmark$ \\
\hline Digital Learning Resources & $\checkmark$ & $\checkmark$ & $\checkmark$ & $\checkmark$ & $\checkmark$ & $\checkmark$ & $\checkmark$ & $\checkmark$ & $\checkmark$ & $\checkmark$ & $\checkmark$ \\
\hline
\end{tabular}




\subsection{Analysis of the Types of Virtual Learning Resource for the Digital Manpower}

Table 2. Analysis of the types of virtual learning resource for the digital manpower

\begin{tabular}{|c|c|c|c|c|c|c|c|c|c|c|c|c|}
\hline \multicolumn{2}{|c|}{ The types of virtual learning resource for the digital manpower } & 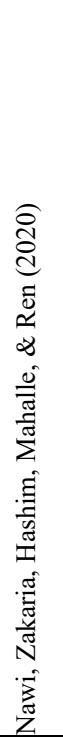 & 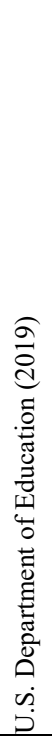 & 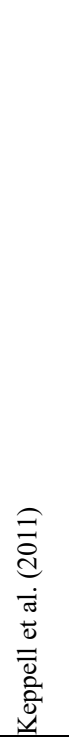 & 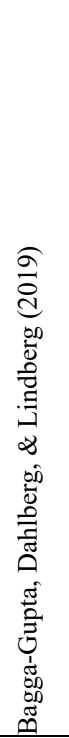 & 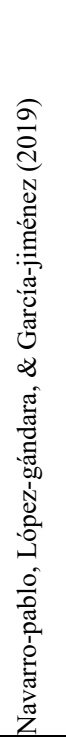 & 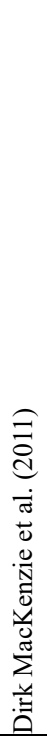 & 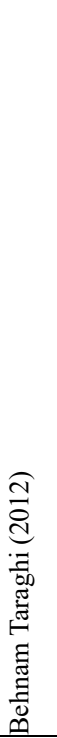 & 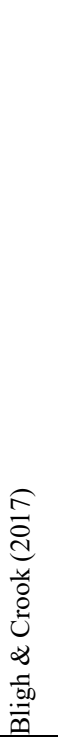 & 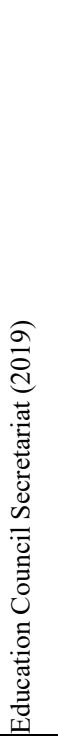 & 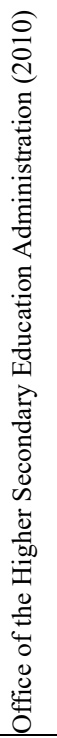 & 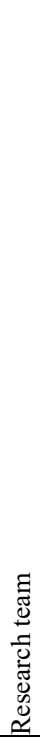 \\
\hline \multirow{5}{*}{ 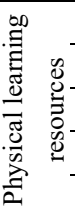 } & location-based learning resources & $\checkmark$ & $\checkmark$ & $\checkmark$ & $\checkmark$ & $\checkmark$ & $\checkmark$ & $\checkmark$ & $\checkmark$ & $\checkmark$ & $\checkmark$ & $\checkmark$ \\
\hline & human-based learning resources & $\checkmark$ & $\checkmark$ & $\checkmark$ & $\checkmark$ & $\checkmark$ & $\checkmark$ & $\checkmark$ & $\checkmark$ & $\checkmark$ & $\checkmark$ & $\checkmark$ \\
\hline & material-based learning resources, & & & & $\checkmark$ & $\checkmark$ & $\checkmark$ & & $\checkmark$ & $\checkmark$ & $\checkmark$ & $\checkmark$ \\
\hline & equipment-based learning resources & $\checkmark$ & $\checkmark$ & $\checkmark$ & $\checkmark$ & $\checkmark$ & $\checkmark$ & $\checkmark$ & $\checkmark$ & $\checkmark$ & $\checkmark$ & $\checkmark$ \\
\hline & event-based learning resources & $\checkmark$ & $\checkmark$ & $\checkmark$ & $\checkmark$ & $\checkmark$ & $\checkmark$ & $\checkmark$ & $\checkmark$ & $\checkmark$ & $\checkmark$ & $\checkmark$ \\
\hline \multirow{5}{*}{ 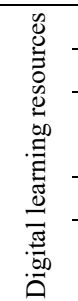 } & search engine and translators tools & $\checkmark$ & & $\checkmark$ & $\checkmark$ & $\checkmark$ & $\checkmark$ & $\checkmark$ & $\checkmark$ & $\checkmark$ & $\checkmark$ & $\checkmark$ \\
\hline & management and storage tools & & $\checkmark$ & $\checkmark$ & $\checkmark$ & $\checkmark$ & $\checkmark$ & & $\checkmark$ & $\checkmark$ & $\checkmark$ & $\checkmark$ \\
\hline & $\begin{array}{l}\text { content creation tools, presentation and dissemination } \\
\text { tools }\end{array}$ & $\checkmark$ & $\checkmark$ & $\checkmark$ & $\checkmark$ & $\checkmark$ & $\checkmark$ & $\checkmark$ & $\checkmark$ & $\checkmark$ & $\checkmark$ & $\checkmark$ \\
\hline & distance learning tools & $\checkmark$ & $\checkmark$ & $\checkmark$ & & $\checkmark$ & $\checkmark$ & $\checkmark$ & & $\checkmark$ & $\checkmark$ & $\checkmark$ \\
\hline & $\begin{array}{l}\text { social networking and online learning communities } \\
\text { tools }\end{array}$ & $\checkmark$ & $\checkmark$ & $\checkmark$ & $\checkmark$ & $\checkmark$ & $\checkmark$ & $\checkmark$ & & $\checkmark$ & $\checkmark$ & $\checkmark$ \\
\hline
\end{tabular}

From Table 2, an analysis of types of virtual learning resource for the digital manpower, the types of virtual learning resources in the digital age can be summarized as detailed below.

Physical learning resources, it is characterized by as physical spaces that the learners can touch (Temple \& Fillippakou, 2007; Wall, 2016; Fernández-Pampillón, 2017). The management of physical learning resources must include a consideration of the context of the career pathways, working environment of the aging workforce learners in each group, which can be divided into 5 categories as follows:

1) Location-based Learning Resources: public library/community ICT learning center, museum, art gallery, zoo, public park, botanical garden, science park and technology, sports and recreation centers, religious places (temples/churches/viharns/mosques), school/short-term vocational training school/short-term vocational training center, sub-district non-formal education/district non-formal education/province non-formal education, industrial and community education college/technical college/community college, universities/vocational institutions, workplace/area or professional workplace, residence, and shopping center/department store.

2) Human-based Learning Resources: interaction or exchanging learning with "colleagues in the organization" for learning, interacting or exchanging learning with "colleagues from different organizations" for learning, interacting or exchanging learning with "classmates in the past" for learning, interaction or exchange of knowledge with "chief/supervisor" for learning, interaction or exchange of knowledge with subordinates/subordinates for learning, interaction or exchange of learning with family members/relatives for learning, interaction or exchange of learning with "teachers/tutors" for learning, and interaction or exchange of knowledge with "professional specialists" for learning. 
3) Material-based Learning Resources: books, magazines, pamphlets/journal, thesis/research report, newspaper, posters, brochure, information boards/bulletin board, instructional CD/DVD, flash drive for learning, and professional working material.

4) Equipment-based Learning Resources: desktop computer, portable computer (laptop/notebook), smart phone, smart TV, tablet, radio/TV (not connected to the Internet), smart wearables, and professional or other functional devices.

5) Event-based Learning Resources: coaching and mentoring, counseling, training, study visit, seminar, academic conference, graduate education, general meeting, and activities in professional work or others.

Digital learning resources are characterized by being virtual spaces that learners can access through information and communication technology, where managing learning resources in a virtual space requires consideration of media exposure (Zeivots \& Schuck, 2018; Navarro-pablo et al., 2019; Carvalho et al., 2020; Woods, 2020) and lifestyle of Aging Workforce Learners in each group, it can be divided into 5 categories as follows:

1) Search engine and translators tools: Google Search, Baidu.com, Yahoo.com, Bing.com, Google Maps, Google Translate, Microsoft Translator, Speak \& Translate-Translator, Scan \& Translate, LINE English-Thai Dictionary, I love Translation (en.ilovetranslation.com), Longdo Dictionary, and Trip advisor, etc.

2) Management and storage tools: Google Chrome, Mozilla Firefox, Microsoft Internet Explorer, Microsoft Edge, Opera, Google Drive, One Drive/Sky Drive, iCloud, Dropbox, Box, Google Calendar, Outlook Calendar/Microsoft Calendar, Google Assistant, Siri by Apple, etc.

3) Content creation tools, presentation and dissemination tools: Wiki/Wikipedia.com, wikiHow.com, Google Docs, Google Sheets, Google Forms, Microsoft Word, Microsoft Excel, Microsoft PowerPoint, Microsoft OneNote, Microsoft SharePoint, Adobe Creative Cloud, Google Slides, Google Site, YouTube, Wix.com, Weebly.com, SlideShare, Prezi, Mentimeter, Poll Everywhere, Kahoot, Socrative, NearPod, Plickers, Microsoft Office Mix, Pinterest, etc.

4) Distance Learning Tools: MOOC, edX, Coursera, XeutangX, Udemy, Google Classroom, Edmodo, MOODLE, TED Talks, Instructional VDO Playlist on YouTube, Digital Learning Platform by Google, Digital Learning Platform by Microsoft, Cisco Webex, FutureLearn, etc.

5) Social Networking and Online Learning Communities Tools: Facebook, Facebook Messenger, Instagram, WhatsApp, LINE, Twitter, Workplace by Facebook, Microsoft Teams, Microsoft Yammer, Snapchat, ResearchGate, Academia.edu, Slack, Skype, Zoom, Google Meet.

The researcher has reviewed literature from books, documents, articles, research reports, and research databases both domestically and internationally on Virtual Learning Resources Center (VLRC) for the digital manpower. For the study of models and types of VLRC, it was found that the models of VLRC for the digital manpower consisted of 1) model 1: The physical learning source model and 2) model 2: The digital learning source model (us department of education, 2019). The development of VLRC for the digital manpower can be achieved in three ways: 1) physical space development, 2) virtual space development, and 3) integrated learning development or seamless learning development, which is a harmonious and unified combination of physical learning environment and digital learning environment.

3.3 Components of the Digital Age Virtual Learning Resource Development Model Suitable for the Digital Manpower

The virtual learning resource development model for the digital manpower consists of 3 components:

\subsubsection{Goals of Virtual Learning Resource Development}

The Goals of Virtual Learning Resource Development is an important component in terms of Goals Setting, in promoting Lifelong Learning of the Aging Workforce Learners, so that learners who are about to enter the working-age, in the working-age, as well as learners who are leaving the working-age, can continue to improve their quality of life, appropriately, and in accordance with the nature of the age-transition, according to the principle of "four pillars of education" and Lifelong learning of the United Nations Educational, Scientific and Cultural Organization: UNESCO (UNESCO, 2014; Appadoo et al., 2014) consists of:

1) Learning to know: It is the development of a learning resource with the goal of promoting the Aging Workforce Learners to concentrate, know how to seek knowledge, have thought processes, and effective learning methods.

2) Learning to do: It is the development of a learning resource with goals, focusing on promoting the Aging 
Workforce Learners, bringing the competence and ability, including professional competencies into practice.

3) Learning to live together: It is the development of learning resources to promote Aging Workforce Learners to live happily with others in a multicultural society.

4) Learning to be: It is the development of a learning resource with a goal, focusing on promoting the Aging Workforce Learners to develop mental, physical, and intellectual development, with a focus on the development of multiple Intelligences of individuals with diverse.

\subsubsection{Virtual Learning Resources Center}

The Virtual Learning Resources Center is an important component of the Learning Environment Managements (LEMs) in the Physical Learning Environments (PLEs), the Digital Learning Environment (DLEs), and Seamless Learning Environments (SLEs). This Resources Center is a hub of Data, Information, knowledge, and Wisdom that enables Aging Workforce Learners in the digital age to access and utilize learning resources from every time, from everywhere, and from any device, especially on digital devices (Libbrecht, 2015).

1) Physical Learning Resources: There are key features which are physical spaces that are tangible. The management of physical learning resources must include a consideration of the context of the Career Pathways and the workplace environment of the Aging Workforce Learners in each group. Physical learning resources can be classified into 5 groups: 1) the location-type learning resource group, 2) the individual learning resource group, 3) the material learning resource group, 4) the Device type learning resource group, and 5) Activity/event type learning resource group (Keppell et al., 2011).

2) Digital Learning Resources: An important feature is that it is a virtual space that learners can access through information and communication technology, where the management of physical learning resources must take into account the Media Exposure and Lifestyle of Aging Workforce Learners in each group, the digital learning resources can be classified into 5 groups: 1) tool-type learning resources group, Data search and translation, 2) tools for data management and storage, 3) content creation, presentation and publishing tool types, 4) tool-type learning resources groups, Distance learning, and 5) social networking type learning resource/online learning community (Camilleri \& Camilleri, 2017; Rozo \& Real, 2019).

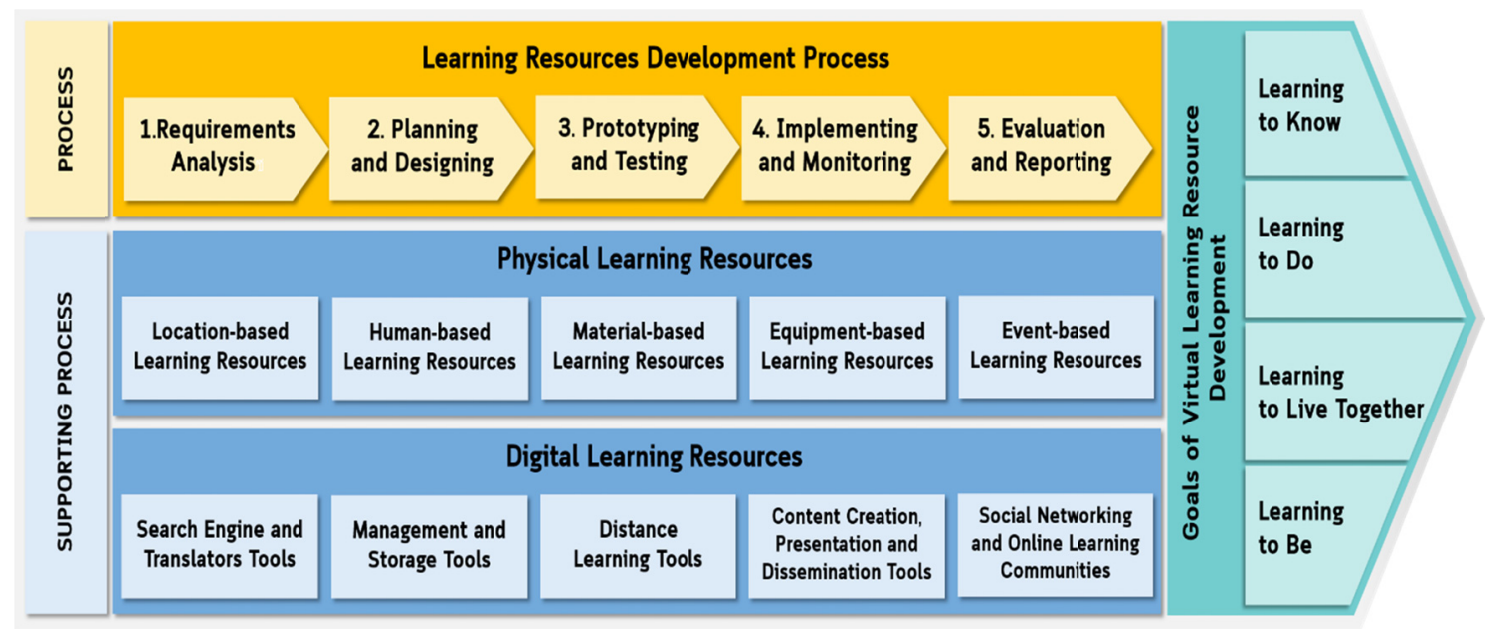

Figure 1. The valued chain model for virtual learning resource center development

\subsubsection{Digital Manpower}

The Digital Manpower is a critical component in terms of targeting Group of Aging Workforce Learners who are digital manpower, such as learners entering the Aging Workforce, Aging Workforce Learners, and learners leaving the Aging Workforce, which must develop in accordance with Thailand 4.0 policy to develop long-term manpower (Chan-o-cha, 2017), both the formal and non-formal working-age is the new generation of manpower to work with digital technology (Thailand Development Research Institute, 2018), consisting of 1) formal Aging Workforce Learners, can be classified into 12 groups, and 2) informal Aging Workforce Learners, can be classified into 2 groups, with details as follows.

1) Formal Digital Manpower Learner: It is a system worker with fixed income, fixed salary, and the formal aging 
workforce that is covered by law as required. In addition, formal workers have the opportunity to advance in their work lives and receive protection from social insurance, aging insurance and health insurance. Formal workers can be categorized into 12 types: 1) Aging Workforce Learners, education profession, 2) Aging Workforce Learners, public health professionals, 3) Aging Workforce Learners, Agriculture, Livestock, and Fisheries Profession 4) Aging Workforce Learners, Engineering and Manufacturing Profession, 5) Aging Workforce Learners, Architecture and design professions, 6) Aging Workforce Learners, Information and Communication Technology Profession, 7) Aging Workforce Learners, Finance, Real Estate. and Accounting Profession, 8) Aging Workforce Learners, Mass Communication Profession, 9) Aging Workforce Learners, Transportation and Logistics Profession, 10) Aging Workforce Learners, Professional groups in service, tourism and sports, 11) Aging Workforce Learners, Professional groups in performing arts, and entertainment, and 12) Aging Workforce Learners, professional entrepreneurial groups, by registered. Formal Aging Workforce Learners must be developed for the digital age (Puriwat \& Tripopsakul, 2020a).

2) Informal Digital Manpower Learner: It is a freelance worker or a non-protected worker in the social security system. This group of worker can be divided into 5 categories: 1) Aging Workforce Learners, General independent professional groups such as beautician, barber, food seller cooked to order dish, driver, hire, hawker, stall, farmer, gardener, etc.; 2) Aging Workforce Learners, private business groups, without Registration, such as online sales, online product dealers, etc.; 3) Aging Workforce Learners, those with independent employment, who do not directly depend on the agency. (Freelancers/Outworkers) such as freelance photographers, freelance videographers, freelance designers, etc.; 4) Aging Workforce Learners, part-time workers, such as convenience store employees, public relations staff, supporting actor, etc.; and 5) Aging Workforce Learners, working groups in agriculture, industry, and services, but without social security such as employees with regular salaries, but without social security. All sectors of the workforce must be developed equally with digital transformation (Maesincee, 2016).

\section{Method}

The Virtual Learning Resource Center Development Process suitable for the digital manpower learners

It is an important process in developing a virtual learning resource center in the digital manpower in the working-age learners. There are 5 main steps in this process as follows:

\section{Step 1: Requirements Analysis}

It is a process for studying the development of virtual learning resources in the digital age for the Aging Workforce Learners to supply a basis for agencies/organizations that want to develop learning resources, use them in planning and design learning resources by the vision, mission, and goals of the agencies/organizations, as well as meeting the needs of working-age learners. The requirements analysis consists of 3 subs-steps as follows:

1.1) Analysis of needs of agencies/organizations about the promotion and development of human resources, according to the Career Pathways, working environment of the Aging Workforce Learners in each group or in each unit/organization, to have knowledge, skills, and Attributes that needed to perform Job Roles or in a particular subject better.

1.2) Analyzing the needs of target groups. It is a demand analysis of the characteristics of virtual learning resources, media demand, technology requirements presentation, as well as the study of Media Exposure behavior, the study of happiness of people in the organization (Happy Workplace) and Lifestyle, both in Demographic dimensions, Activities, Interest, and Opinion of the Aging Workforce Learners in each group or in each agency/organization.

1.3) Determination of the Objectives of Learning Resources Development. It is the results of the needs analysis of the agency/organization and the results of the analysis of the needs of the target groups in deciding the aims of the development of virtual learning resources for Aging Workforce Learners in each group or in each agency/organization. It is divided into 4 main aims: 1) the development of learning resources that focus on promoting learning, 2) the development of learning resources that focus on promoting learning for practical purposes, 3 ) the development of learning resources that promote coexistence, and 4) the development of learning resources that promote learning for life (Gordillo, López-Fernández, \& Verbert, 2020).

\section{Step 2: Planning and Designing}

It is a process that involves thinking and making decisions of executives and those involved in agency/organizations in the Idea Generation, including developing an ingenious pre-programmed virtual learning resource development plan, as well as formulating, checking methods, and evaluating the success of the use of learning resources (Argyriou, Economou, \& Bouki, 2020), consists of 3 subs-phases: 
2.1) The creation of innovative ideas; It is the concept of the development of virtual learning resources center of the agency/organization that will bring the information obtained from the analysis of that need. Such information is to be used to create the concept of learning resources development that meets the needs of target groups and agency/organizations where ideas are to be assessed for feasibility. The best and most suitable ideas will be selected for use in developing a plan for further development.

2.2) Establishing a virtual learning resource center development plan and shaping the learning environment of the virtual learning resource; It is Planning Time Frames, plans can be classified into 3 types: 1) long term plans, 2) medium-term plans, and 3) short term plans. These plans will take more than 5 years, 3-5 years, and 1-2 years, respectively. The duration of planning time frames depends on the agency/organization practice. A consideration of such duration should cover in 4 areas:

2.2.1) Issues about the Target Group; Targeting can be done in various ways, such as 1) Demographic segmentation, 2) Target group classification by professional group/occupation,3) Targeting groups according to the occupation/occupation period, such as learners about to enter working-age, learners in working-age, and learners who are leaving the working-age in each group or in each agency/organization, including other contextual targeting such as learners who want to learn themselves and have a personal learning resource (Moon, Do, Lee, \& Choi, 2020.)

2.2.2) Issues about the Goals; it is the setting of goals or aims of a virtual learning resource center development plan, by considering the goals specific and clear, statistically measurable, possible and achievable. The goals set are consistent with reality and have clear target timing.

2.2.3) Issues about the Scope: It shapes the learning environment of the virtual learning resource center that can be divided into 3 types: 1) physical learning environment, 2) digital learning environment, and 3) a seamless learning environment.

2.2.4) Issues about the Time: This is the question of how much time each operation will take. It can be set as yearly, quarterly (Three-month), monthly, or weekly, so that administrators and those involved in the organization/organization can see an overview of the development of virtual learning resources.

2.3) Determining methods for monitoring and evaluating the success of the use of virtual learning resources center is the determination of the tools used for monitoring and evaluating the success of the use of virtual learning resources in Physical, digital learning environment model, and seamless learning environment model, by using learner's trace/evidence of learning to use virtual learning resources, divided into 2 characteristics: 1) the Goal-based Evaluation, which is an assessment that focuses on the checks between the results achieved and the objectives of the project (Jiang, Pardos, \& Wei, 2019). This evaluation is of the response to the learning resources and evaluation of learning outcomes. 2) The Goal-Free Evaluation, which is an assessment that focuses on examining whether or not the results achieved in the implementation of the project are in line with the aims set. This includes other results and effects that affect the value or results of the agency/organization.

Step 3: Prototyping and Testing is a process of converting abstraction into concrete and tangible

This is the result of planning and designing virtual learning resources. To be used to prototype virtual learning resources according to the virtual learning resource center development plan and to conduct quality testing of virtual learning resources with expert groups and preliminary testing with target groups, to improve learning resources. As to the quality before applying to the next step (Pardo, Parycek, Janssen, Zheng, \& Cunha, 2017), this step consists of 3 subs-steps as follows:

3.1) Virtual Learning Resource Center Prototyping is a learning center prototype, based on the goals, scope, and timing of the agency/organization's virtual learning resource development plan. It can be divided into three aspects: 1) physical learning source prototyping, 2) digital learning source prototyping, and 3) seamless learning source prototyping.

3.2) The quality audit and testing of virtual learning resources is the quality examination of the modern learning resources by specialized experts, and preliminary testing on identified target groups, according to the virtual learning resource development plan of the agency/organization.

3.3) Improving the quality of virtual learning resources center: It is the application of expert opinions and target groups found following the agency/organization's virtual learning resource development plan to improve the quality of the virtual learning resources until it is recognized by an expert or target audience.

Step 4: Implementing and Monitoring

It is the process of promoting virtual learning resources center, supplying services/managing virtual learning 
resources, and checking the use of virtual learning resources, which is the implementation of modern learning source models. That has been accepted by experts or target groups to be used in expanding the Aging Workforce Learners that have been found, according to the virtual learning resource development plan of agencies/organizations, to access and use virtual earning resources (H. Slater et al., 2020), consists of 3 subs-steps:

4.1) Promoting virtual learning resources: It is the use of various communication channels to give the modern learning resources of the agency/organization, aiming at building knowledge and understanding with the target group about accessibility, and taking advantage of virtual learning resources.

4.2) Virtual learning resource service and management: is to build relationships with target groups as service recipients of virtual learning resources in meeting the needs or solving problems related to the use of virtual learning resources, both as a physical learning resource and a digital learning resource or a seamless learning resource, with a focus on satisfying the target audience, finally, leading to the acceptance of the virtual learning resource.

4.3) Monitoring the use of virtual learning resources: It is the application of information and communication technology tools to be used as a tool for checking the use of virtual learning resources on various issues, such as access to services (Access), Meet the needs (Responsiveness), Communication, Credibility, and Security or other issues that decide the service quality of the virtual learning resource, however, is not fixed, depending on the nature of the learning resource.

\section{Step 5: Evaluation and Reporting}

This is the process of reviewing, collecting, analyzing and summarizing the results of the use of modern learning resources to compare them with the goals set as planned according to the virtual learning resource development plan of the agency/organization how effective that as specified is, it is to use the reported data in reviewing the management's virtual learning resource development program, including those who involved within an agency/organization (Laeeq Khan, Welser, Cisneros, Manatong, \& Idris, 2020), consisting of 3 sub-phases:

5.1) Evaluation and reporting of responses to learning sources: This is to examine, collect, analyze, and summarize information about the target group's opinions and preferences towards virtual learning resources, including the learning engagement of the target groups arising from the virtual learning resources.

5.2) Evaluation and reporting of learning outcomes: This is to examine, collect, analyze, and summarize information about the target group's learning outcomes, according to the goal of promoting lifelong learning of the Aging Workforce Learners, consisting of 1) Learning to know, 2) Learning to do, 3) Learning to live together, and 4) Learning to be, which may be examined to cover both Knowledge, Skills, and Attitude as well.

5.3) Evaluation and reporting of results to agencies/organizations: This is to examine, collect, analyze, and summarize information about the results or the impact on the agency/organization. It also enables us to check the quality of work, and assess whether the work of the people in the organization and their quality of work have improved. 


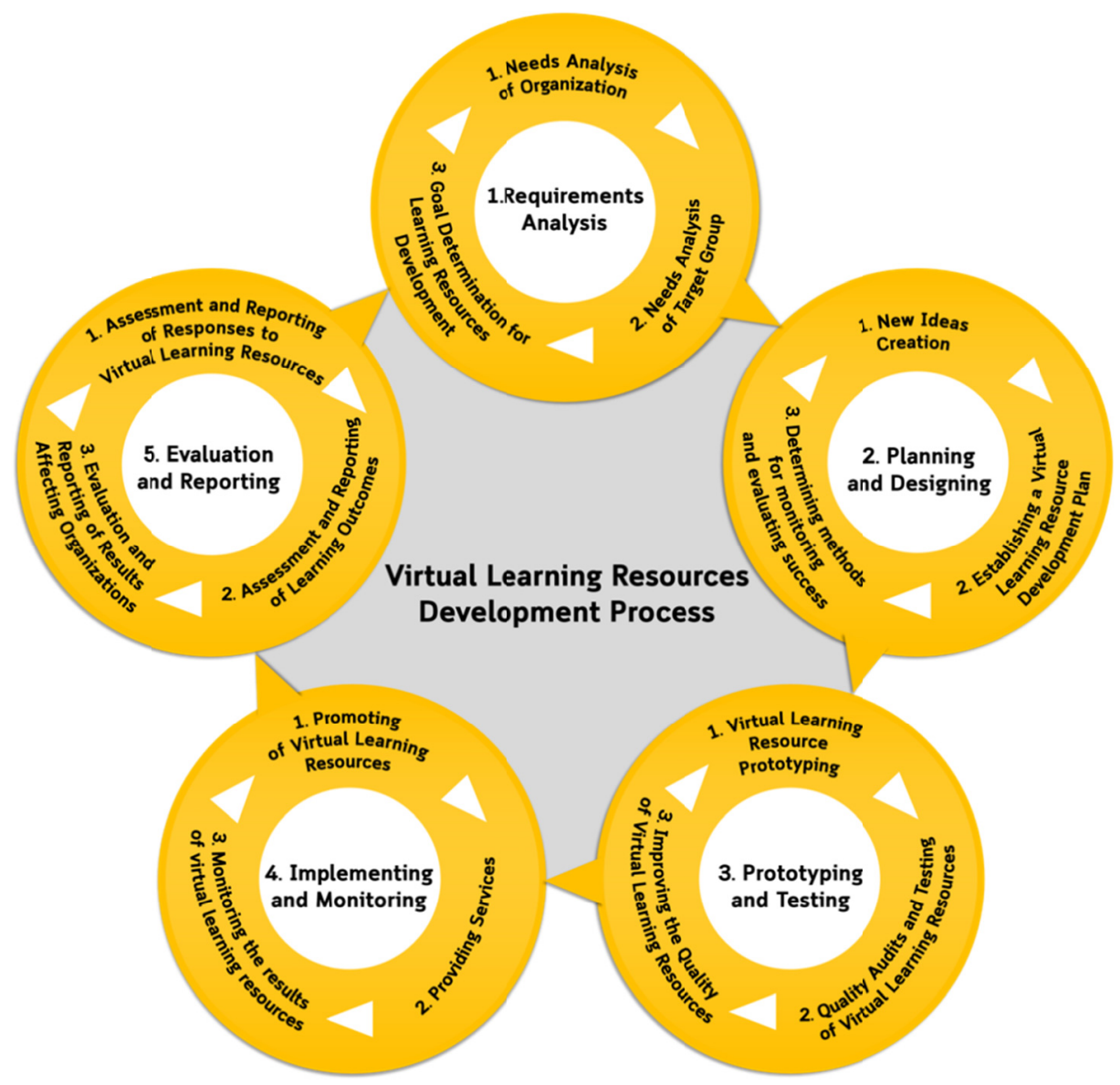

Figure 2. The virtual learning resource development process suitable for the learners in the digital age

From Figure 2, the framework of the virtual learning resource development process suitable for the learners in the digital age was evaluated by using consensus evaluation from seventeen experts by using Mean, Standard Deviation: S.D., Median, Interquartile Range: IR and Quartile Deviation: QD. The evaluation consensus results from seventeen experts regarding the processes found that mean equals more than 4.50 (expert group strongly agrees) and standard deviation equals less than 1 (expert groups with high consensus). In considering the interquartile range and quartile deviation, it was found that interquartile range of each indicator is not more than 1.0 and quartile deviation is not more than 0.5 means expert groups with high consensus. The evaluation results of the framework of the virtual learning resource development process suitable for the learners in the digital age shown in Table 3.

Table 3. Evaluation results of virtual learning resource development process suitable for the learners in the digital age

\begin{tabular}{|c|c|c|c|c|c|c|c|}
\hline \multirow{2}{*}{ Process } & \multirow{2}{*}{ Mean } & \multirow{2}{*}{ S.D. } & \multicolumn{3}{|c|}{ Quartile } & \multirow{2}{*}{ IR } & \multirow{2}{*}{ QD. } \\
\hline & & & Q1 & Q2 & Q3 & & \\
\hline \multicolumn{8}{|l|}{ 1) Requirements Analysis } \\
\hline 1. Needs Analysis of Organization & 4.82 & 0.39 & 5 & 5 & 5 & 0.00 & 0.00 \\
\hline 2. Needs Analysis of Target Group & 4.76 & 0.44 & 5 & 5 & 5 & 0.00 & 0.00 \\
\hline 3. Goal Determination for Learning Resources Development & 4.71 & 0.47 & 4 & 5 & 5 & 1.00 & 0.50 \\
\hline Summary & 4.76 & 0.43 & & & & & \\
\hline \multicolumn{8}{|l|}{ 2) Planning and Designing } \\
\hline 1. New Ideas Creation & 4.76 & 0.44 & 5 & 5 & 5 & 0.00 & 0.00 \\
\hline 2. Establishing a Virtual Learning Resource Development Plan & 4.76 & 0.44 & 5 & 5 & 5 & 0.00 & 0.00 \\
\hline 3. Determining methods for monitoring and evaluating success & 4.76 & 0.44 & 5 & 5 & 5 & 0.00 & 0.00 \\
\hline
\end{tabular}




\begin{tabular}{|c|c|c|c|c|c|c|c|}
\hline Summary & 4.76 & 0.44 & & & & & \\
\hline \multicolumn{8}{|l|}{ 3) Prototyping and Testing } \\
\hline 1. Virtual Learning Resource Prototyping & 4.71 & 0.47 & 4 & 5 & 5 & 1.00 & 0.50 \\
\hline 2. Quality Audits and Testing of Virtual Learning Resources & 4.71 & 0.47 & 4 & 5 & 5 & 1.00 & 0.50 \\
\hline 3. Improving the Quality of Virtual Learning Resources & 4.71 & 0.47 & 4 & 5 & 5 & 1.00 & 0.50 \\
\hline Summary & 4.71 & 0.47 & & & & & \\
\hline \multicolumn{8}{|l|}{ 4) Implementing and Monitoring } \\
\hline 1. Promoting of Virtual Learning Resources & 4.76 & 0.44 & 5 & 5 & 5 & 0.00 & 0.00 \\
\hline 2. Providing Services & 4.76 & 0.44 & 5 & 5 & 5 & 0.00 & 0.00 \\
\hline 3. Monitoring the results of virtual learning resources & 4.76 & 0.44 & 5 & 5 & 5 & 0.00 & 0.00 \\
\hline Summary & 4.76 & 0.44 & & & & & \\
\hline \multicolumn{8}{|l|}{ 5) Evaluation and Reporting } \\
\hline 1. Assessment and Reporting of Responses to Virtual Learning Resources & 4.71 & 0.47 & 4 & 5 & 5 & 1.00 & 0.50 \\
\hline 2. Assessment and Reporting of Learning Outcomes & 4.71 & 0.47 & 4 & 5 & 5 & 1.00 & 0.50 \\
\hline 3. Evaluation and Reporting of Results Affecting Organizations & 4.76 & 0.44 & 5 & 5 & 5 & 0.00 & 0.00 \\
\hline Summary & 4.73 & 0.46 & & & & & \\
\hline
\end{tabular}

\section{Results of Research and Discussion}

The digital virtual learning resource suitable for aging workforce learners, the researcher has researched and developed a model, with four key components: part 1: goals of virtual learning resource development, part 2: virtual learning resource development process, part 3: virtual learning resources, and component 4: digital manpower, by showing the model as follows. 


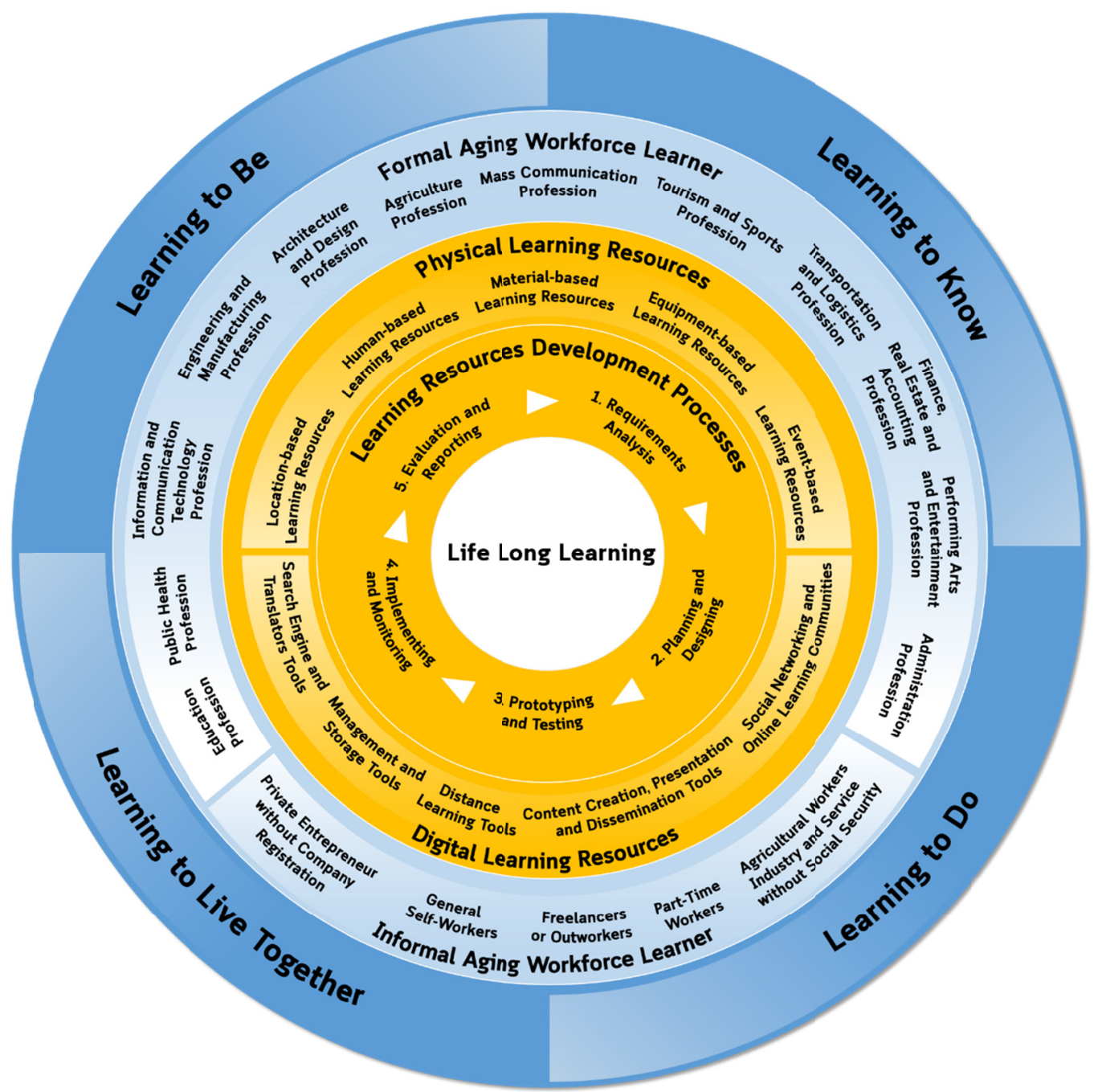

Figure 3. The learning resources in the digital age suitable for digital workforce learners

From Figure 3, the framework of the learning resources in the digital age suitable for digital workforce learners was evaluated by using consensus evaluation from seventeen experts by using Mean, Standard Deviation: S.D., Median, Interquartile Range: IR and Quartile Deviation: QD. The evaluation consensus results from seventeen experts regarding the elements found that mean equals more than 4.50 (expert group strongly agrees) and standard deviation equals less than 1 (expert groups with high consensus). In considering the interquartile range and quartile deviation, it was found that interquartile range of each indicator is not more than 1.0 and quartile deviation is not more than 0.5 means expert groups with high consensus. The evaluation results of the framework of the learning resources in the digital age suitable for digital workforce learners shown in Table 4. 
Table 4. Evaluation results of the framework of the learning resources in the digital age suitable for digital workforce learners

\begin{tabular}{|c|c|c|c|c|c|c|c|}
\hline \multirow{2}{*}{ Elements } & \multirow{2}{*}{ Mean } & \multirow{2}{*}{ S.D. } & \multicolumn{3}{|c|}{ Quartile } & \multirow{2}{*}{ IR } & \multirow{2}{*}{ QD } \\
\hline & & & Q1 & Q2 & Q3 & & \\
\hline Learning Resources Development Processes & 4.94 & 0.24 & 5 & 5 & 5 & 0.00 & 0.00 \\
\hline Physical Learning Resources & 4.82 & 0.39 & 5 & 5 & 5 & 0.00 & 0.00 \\
\hline Digital Learning Resources & 4.82 & 0.39 & 5 & 5 & 5 & 0.00 & 0.00 \\
\hline Formal Aging Workforce Learner & 4.88 & 0.33 & 5 & 5 & 5 & 0.00 & 0.00 \\
\hline Informal Aging Workforce Learner & 4.88 & 0.33 & 5 & 5 & 5 & 0.00 & 0.00 \\
\hline $\begin{array}{l}\text { The Four Pillars of Education (Learning to Know, Learning to Do, Learning to Live } \\
\text { Together and Learning to Be) }\end{array}$ & 4.88 & 0.33 & 5 & 5 & 5 & 0.00 & 0.00 \\
\hline Summary & 4.87 & 0.34 & & & & & \\
\hline
\end{tabular}

The virtual learning resources for digital workforce learners:

A digital virtual learning resource suitable for digital workforce learners consists of 5 main steps, and 15 subs-stages. Five main steps are: 1) needs analysis, 2) planning and design, 3) prototyping and testing, 4) implementation and monitoring, and 5) evaluation and reporting, which takes into account the context/environment, goals, methods and assessments of the agency/organization. It is also important to take into account the development of such learning resources, the trend of designing virtual learning resources in the digital age, the design of a learning area with a human or user-centered focus, or the design of a learning area by the needs of the user (Lahav, Talis, Gali, \& Albert, 2019). The design is guided by the concept of universal human needs and the principles of learning, i.e. humans need both physical and mental comfort, and a wide variety of learning styles, at the same time diverse brain functions, learning areas influence learning (Granito \& Santana, 2016).

The Assessment results for the suitability of virtual learning resources for digital workforce learners:

Therefore, the design of a learning space should be flexible and meet the various needs of users, for the nature of designing a human or user-centered virtual learning resource, by developing virtual learning resources in the digital age (Woods, 2020), the Aging Workforce can be done in three ways: 1) developing physical learning resources, 2) developing digital learning resources, and 3) Developing a blended learning resource or seamless learning resources, in line with the concept of Watson (2013) proposing that the virtual learning resource is a highly flexible space, accepting a wide range of activities as a seating area. A wide variety of forms, portable, chatting facilities, brainstorming such as smart boards, computers with Internet access, as well as taking into account the provision of support for the user's electronic equipment, such as a power outlet and Internet connection point. Such provision can be modified from a traditional classroom, computer lab, or use of library space, in the same way as Brown (2005), suggesting that Virtual learning resources span: 1) physical learning spaces, that is rooms/buildings used for organizing learning activities or facilitating learning, 2) virtual learning spaces as environments in the provision of e-learning, and 3) an offshore learning area, which can be used as an internship learning area. Learning by work or skill training (Luetkemeyer, Mardis, \& Building, 2016), referred to as a practical learning area, may also cover a mobile learning apparatus learning area, that is, every place where learners carry their mobile learning device with them. (Yilan, 2019).

As for the development of virtual learning resources in the digital age suitable for the Aging Workforce learners for agencies/organizations concerned with authority, duties, and responsibilities about the development of learning resources, it is necessary to gain a deep understanding of the context of each professional/career target group, learners' learning behavior. (Opartkiattikul, Arthur-Kelly, \& Dempsey, 2014), As the contexts of different professions/careers could differ in terms of the Career Pathways and rapidly changing digital work environments, future learning resources, it will be a Learning Space (Elkington \& Bligh, 2019) that evolves from the rapid discovery of new things every day, making existing knowledge a shorter lifespan. The modernization of knowledge is becoming obsolete in a noticeably brief time (Vivitsou, 2019) as technology is constantly evolving. Changes in technology and innovation will affect both employment and careers with changing job styles and styles (Brown, Lloyd, \& Souto-otero, 2018), with a growing demand for high-performing workers. Many professions may disappear from the current job market and some careers will be replaced by automation, transforming the direction of learning, shifting from learning how and what to know to learn where to get knowledge. Informal learning is, therefore, essential to the learning experience, learning arises from a variety of methods such as from the community, from the network of people, and by completing the task, learning is an ongoing process (Bashay, 2020). 
Therefore, the development of virtual learning resources in the digital age is essential to setting goals for promoting Lifelong Learning of the Aging Workforce learners. Thailand's key policy is to widen educational opportunities (Luka \& Sumalee, 2015). This policy enables those learners who are leaving the Aging Workforce to develop their quality of life continuously and appropriately. According to the nature of the transitional age in principle "The Four Pillars of Education" (Scatolini, Van Maele, \& Bartholomé, 2010), consists of 1) Learning to know: It is the development of a learning resource aimed at encouraging young learners. Concentrate $=$ know the pursuit of knowledge, have effective thinking processes and learning methods, 2) Learning to do: It is the development of a learning resource with a goal that focuses on promoting the Aging Workforce learners have the ability and ability, including professional competencies for practical work, 3) Learning to live together: It is the development of learning resources. The goal is to promote the Aging Workforce learners to live happily with others in a multicultural society, and 4) Learning to be: developing a learning resource that has its goal is to encourage the Aging Workforce learners to developmental, physical, and intellectual development with a focus on the development of multiple intelligences of individuals.

\section{Conclusion}

The learning resource of the learners in the labor age is a learning center for lifelong learning and a non-formal education for developing manpower in a NEXT normal education era to live happily and work at full efficiency by using traditional physical learning resources and modern digital learning resources. Digital citizen can access knowledge and can learn on demand anytime and anywhere via the Internet because knowledge in today's world is no longer just available at schools or in classrooms. All learners can now access learning resources from various devices which they use in their daily lives. Learning resources in the present time that have changed from the way of life in school age, as well as tools and devices that allow everyone to easily access the learning resources. As a result, working people have to adjust their learning methods and develop themselves in order to create lifelong learning and live happily in a working society.

\section{Acknowledgements}

This research was supported by the Office of the Education Council, Ministry of Education, Thailand. For all research support, Innovation and Technology Management Research Center and Vocational Education Technology Research Center at the Science and Technology Research Institute, King Mongkut's University of Technology North. Bangkok which supported this research. Thank you Assoc. Prof. Dr. Pallop Piriyasurawong and Dr. Phibul Choompolpaisal for supplying support and suggestions that are extremely helpful in this research.

\section{References}

Al Musawi, A., \& Amer, T. (2017). Stakeholders' Perceptions of Quality and Potential Improvements in the Learning Resources Centers at Omani Basic Education Schools. International Education Studies, 10(9), 124-140. https://doi.org/10.5539/ies.v10n9p124

Alexander, R. E. (2013). Improving Student Academic Success Through Differentiated Teaching Within A Specialized Learning Resource Center. School of Education, Capella University.

Appadoo, K., Leal, M. B., Eduarda, M., Andrade, D., Kajtar, E., Lampri, A., ... Williams, M. (2014). 52nd Graduate Study Programme United Nations UNESCO IBE Working Group. Geneva: UNESCO IBE Working Group.

Argyriou, L., Economou, D., \& Bouki, V. (2020). Design methodology for $360^{\circ}$ immersive video applications: The case study of a cultural heritage virtual tour. Personal and Ubiquitous Computing. https://doi.org/10.1007/s00779-020-01373-8

Bagga-Gupta, S., Dahlberg, G. M., \& Lindberg, Y. (2019). Virtual Sites as Learning Spaces: Critical Issues on Language Research in Changing Eduscapes. California: Palgrave Macmillan. https://doi.org/10.1007/978-3-030-26929-6

Bashay, M. (2020). Digital Skill for an Equitable Recovery. Washington DC.

Bligh, B., \& Crook, C. (2017). Learning Spaces. In E. Duval, M. Sharples, \& R. Sutherland (Eds.), Technology Enhanced Learning (pp. 69-87). Springer. https://doi.org/10.1007/978-3-319-02600-8_7

Brown, P., Lloyd, C., \& Souto-otero, M. (2018). The Prospects for Skills and Employment in an Age of Digital Disruption: A Cautionary Note. Oxford.

Camilleri, M. A., \& Camilleri, A. C. (2017). Digital Learning Resources and Ubiquitous Technologies in Education. Technology, Knowledge and Learning, 22(1), 65-82. https://doi.org/10.1007/s10758-016-9287-7 
Carvalho, L., Nicholson, T., Yeoman, P., \& Thibaut, P. (2020). Space matters: framing the New Zealand learning landscape. Learning Environments Research, 23(3), 307-329. https://doi.org/10.1007/s10984-020-09311-4

Chalapati, N., \& Chalapati, S. (2020). Building a skilled workforce: Public discourses on vocational education in Thailand. International Journal for Research in Vocational Education and Training, 7(1), 67-90. https://doi.org/10.13152/10.13152/IJRVET.7.1.4

Chan-o-cha, P. (2017, January). Thailand 4.0 means Opportunity Thailand. Thailand Investment Review, 1-3.

Dhirathiti, N. S., \& Pichitpatja, P. (2018). Characteristics and differences of lifelong learning policy implementation for the elderly in Thailand. Educational Research for Policy and Practice, 17(1), 53-68. https://doi.org/10.1007/s10671-017-9219-x

Education Council Secretariat. (2019). Effectiveness of learning resources: dissemination and implementation of learning resource standards. Bangkok: Ministry of Education, Thailand.

Elkington, S., \& Bligh, B. (2019). Future Learning Spaces: Space, Technology and Pedagogy. North Yorkshire: Teesside University.

Fernández-Pampillón, A. M. (2017). The Role of E-Vocabularies in the Description and Retrieval of Digital Educational Resources. Education Sciences, 7(33), 1-38. https://doi.org/10.3390/educsci7010033

Gordillo, A., López-Fernández, D., \& Verbert, K. (2020). Examining the usefulness of quality scores for generating learning object recommendations in repositories of open educational resources. Applied Sciences (Switzerland), 10(13). https://doi.org/10.3390/app10134638

Granito, V. J., \& Santana, M. E. (2016). Psychology of Learning Spaces: Impact on Teaching and Learning. Journal of Learning Spaces, 5(1), 1-8.

Holder, A., \& Bethea-hampton, T. (2018). A Collaborative Project Exploring Open Educational Resources and Virtual Reality. In 2018 Association Supporting Computer Users in Education Proceeding (pp. 34-42). Myrtle Beach, South Carolina.

Hsieh, H., \& Hsieh, H. (2019). education sciences Undergraduates' Out-Of-Class Learning: Exploring EFL Students' Autonomous Learning Behaviors and Their Usage of Resources. Education Sciences, 9(159), 12-17.

Jiang, W., Pardos, Z. A., \& Wei, Q. (2019). Goal-based course recommendation. In ACM International Conference Proceeding Series (pp. 36-45). https://doi.org/10.1145/3303772.3303814

John, B., Thavavel, Jayaraj, J., Muthukumar, A., \& Jeevanandam, P. (2016). Design of Open Content Social Learning that Increases Learning Efficiency and Engagement Based on Open Pedagogy. The Turkish Online Journal of Educational Technology, 15(1), 20-32.

Kaewpijit, J., \& Utsahajit, W. (2010). An Approach to Create a Happy Workplace. In International Conference Decentrailization in Higher Education from a Global Perspective, July 29-30, 2010. Ho Chi Minh City.

Kangpheng, S., Kunlong, S., Mityodwong, S., Sirikul, P., \& Buddeevong, C. (2018). A Development of Systematic Learning Resources Management Process to Strengthen Sufficiency Attributes of Secondary School Students. International Education Studies, 11(12), 42-48. https://doi.org/10.5539/ies.v11n12p42

Keppell, M., Souter, K., \& Riddle, M. (2011). Physical and Virtual Learning Spaces in Higher Education: Concepts for the Modern Learning Environment. New York: IGI Global; Illustrated Edition.

Laeeq Khan, M., Welser, H. T., Cisneros, C., Manatong, G., \& Idris, I. K. (2020). Digital inequality in the Appalachian Ohio: Understanding how demographics, internet access, and skills can shape vital information use (VIU). Telematics and Informatics, 50(March), 1-18. https://doi.org/10.1016/j.tele.2020.101380

Lahav, O., Talis, V., Gali, R., \& Albert, C. (2019). Virtual interactive consulting agent to support freshman students in transition to higher education. Journal of Computing in Higher Education. Springer US. https://doi.org/10.1007/s12528-019-09237-8

Lazem, S. (2019). On Designing Blended Learning Environments for Resource-Challenged Communities. International Journal of Emerging Technologies in Learning, 14(12), 183-192. https://doi.org/10.3991/ijet.v14i12.10320

Libbrecht, P. (2015). Adaptations to a Learning Resource. Acta Didactica Napocensia, 2(1), 67-74.

Luetkemeyer, J. R., Mardis, M. A., \& Building, S. (2016). Applying the Quadratic Usage Framework to 
Research on K-12 STEM Digital Learning Resources. School Library Research, 19(May), 1-25.

Luka, I., \& Sumalee, S. (2015). Lifelong learning strategies and practice in Latvia and Thailand. Policy Futures in Education, 13(4), 529-545. https://doi.org/10.1177/1478210315571222

Maesincee, S. (2016). Thailand 4.0 will focus on investing on people: Minister Suvit Maesincee. Retrieved from https://www.thaipr.net/education/724669

Moon, J., Do, J., Lee, D., \& Choi, G. W. (2020). A conceptual framework for teaching computational thinking in personalized OERs. Smart Learning Environments, 7(1), 2-19. https://doi.org/10.1186/s40561-019-0108-z

Navarro-pablo, M., López-gándara, Y., \& García-jiménez, E. (2019). The use of digital resources and materials in and outside the bilingual classroom. Media Education Research Journal, 59(2), 83-92. https://doi.org/10.3916/C59-2019-08

Nawi, A., Zakaria, G. A. N., Hashim, N., Mahalle, S., \& Ren, C. C. (2020). The Needs of Islamic Digital Resources in Polytechnic Brunei Darussalam. International Journal of Instruction, 13(1), 225-234. https://doi.org/10.29333/iji.2020.13115a

Nilsen, A. G., Almås, A. G., \& Gram, H. (2020). Producing Digital Learning Resources (DLR) for Teacher Training. Designs for Learning, 12(1), 71-80. https://doi.org/10.16993/dfl.153

Office of the Higher Secondary Education Administration. (2010). Digital Literacy: World-Class Standard School. Bangkok: Office of the Basic Education Commission, Ministry of Education.

Opartkiattikul, W., Arthur-Kelly, M., \& Dempsey, I. (2014). From Policy To Practice Supporting Students With Diverse Needs In Thailand: Critical Issues And Implications. International Journal of Whole Schooling, 11(1), 1-18.

Pardo, T. A., Parycek, P., Janssen, M., Zheng, L., \& Cunha, M. A. (2017). Building \& sustaining a digital government research center: A director's perspective. In ACM International Conference Proceeding Series (Vol. Part F1282, pp. 607-609). https://doi.org/10.1145/3085228.3085241

Parsons, D., Inkila, M., \& Lynch, J. (2019). Navigating learning worlds: Using digital tools to learn in physical and virtual spaces. Australasian Journal of Educational Technology, 35(144), 144-159. https://doi.org/10.14742/ajet.3675

Patrix, M., \& Benade, L. (2018). Beyond the Building. Reconceptualising Environments: A Literature Review Learning. New Zealand Journal of Teachers' Work, 15(1), 10-19.

Puriwat, W., \& Tripopsakul, S. (2020a). Preparing for industry 4.0-will youths have enough essential skills?: An evidence from Thailand. International Journal of Instruction, 13(3), 89-104. https://doi.org/10.29333/iji.2020.1337a

Puriwat, W., \& Tripopsakul, S. (2020b). Preparing for Industry 4.0-Will youths have enough essential skills ?: An Evidence from Thailand. International Journal of Instruction, 13(3), 89-104.

Rozo, H., \& Real, M. (2019). Pedagogical Guidelines for the Creation of Adaptive Digital Educational Resources: A Review of the Literature. Journal of Technology and Science Education, 9(3), 308-325. https://doi.org/10.3926/jotse.652

Scatolini, S. A., Van Maele, J., \& Bartholomé, M. (2010). Developing a curriculum for 'learning to live together': Building peace in the minds of people. European Perspectives on Internationalization, 133-158.

Slater, D. R., \& Davies, R. (2020). Student Preferences for Learning Resources on a Land-Based Postgraduate Online Degree Program. Online Learning Journal, 24(1), 140-161.

Slater, H., Stinson, J. N., Jordan, J. E., Chua, J., Low, B., Lalloo, C., ... Briggs, M. (2020). Evaluation of Digital Technologies Tailored to Support Young People's Self-Management of Musculoskeletal Pain: Mixed Methods Study. Journal of Medical Internet Research, 22(6), 1-22. https://doi.org/10.2196/18315

Temple, P., \& Fillippakou, O. (2007). Learning spaces for the 21 st century: A review of the literature. London: Institute of Education, University of London.

Thailand Development Research Institute. (2018). Digital Manpower Development Study Project to support targeted industries (S-Curve) and Development of the Eastern Economic Corridor (EEC). Bangkok: Office of the Promotion of Digital Economy.

U.S. Department of Education. (2019). Supporting English Learners through Technology: What Districts and Teachers Say about Digital Learning Resources for English Learners (Vol. II). Washington, D.C.: 
OneWorld Linguistic Consulting.

UNESCO. (2014). Learning to Live Together: Education Policies and Realities in the Asia-Pacific. Bangkok: UNESCO Bangkok Office.

Vasantanarat, C., Duangkota, C., \& Thikaewsri, N. (2013). Happy Workplace. Bangkok: Happy Workplace Center.

Vivitsou, M. (2019). Digitalisation in Education, Allusions and References. The CEPS Journal, 9(3), 117-136. https://doi.org/10.26529/cepsj.706

Wall, G. (2016). The impact of physical design on student outcomes. Wellington, New Zealand: Ministry of Education, New Zealand.

Woods, K. (2020). The Development and Design of an Interactive Digital Training Resource for Personal Tutors. Frontiers in Education, 5(July), 1-11. https://doi.org/10.3389/feduc.2020.00100

World Bank Group. (2019). Thailand-World Bank Group Country Partnership Framework 2019-2022. Bangkok: World Bank Group.

Yilan, S. M. (2019). Investigating the Use of Online Learning Resources by the EAP Students in a UK University. Journal of Education and Practice, 10(15), 111-117. https://oi.org/10.7176/JEP

Zeivots, S., \& Schuck, S. (2018). Needs and expectations of a new learning space: Research students' perspectives. Australasian Journal of Educational Technology, 34(6), 27-40. https://doi.org/10.14742/ajet.4516

\section{Copyrights}

Copyright for this article is retained by the author(s), with first publication rights granted to the journal.

This is an open-access article distributed under the terms and conditions of the Creative Commons Attribution license (http://creativecommons.org/licenses/by/4.0/). 